\title{
Effect of lycopene in prevention of preeclampsia in high risk pregnant women
}

\section{Yüksek riskli gebe kadınlarda preeklampsinin önlenmesinde likopen'in etkisi}

\author{
Ramalingappa Antartani ${ }^{2}$, Kiran Ashok $^{1}$ \\ 'Helios Clinics, Schwerin, Germany'2Department of Obstetrics and Gynecology, \\ Karnataka Institute of Medical Sciences, Hubli, India
}

\section{Abstract}

Objective: To evaluate the effect of pre-natal supplementation of antioxidant Lycopene in prevention of pre-eclampsia in the high risk pregnant women. We also assessed the effect of lycopene supplementation on intra-uterine growth restriction and the perinatal outcome in women at high risk of developing pre-eclampsia.

Materials and Methods: A total of 54 women between 14-28 weeks of pregnancy who were at high risk of developing pre-eclampsia were considered for the study. Inclusion criteria were women with a previous history of preeclampsia, a growth-retarded fetus, perinatal death, multifetal gestation and chronic hypertension. Of the total of 54 women, 30 women were randomized to receive Lycopene in a dose of 2 $\mathrm{mg}$ twice daily starting from the date of entry and were instructed to continue the drug regularly until delivery. The other 24 women were randomized to the control group and they did not take lycopene. The controls were matched to cases with respect to the risk factors for the development of preeclampsia. Both groups were followed at monthly intervals. In addition, a Doppler assessment for evidence of intrauterine growth retardation was done at around 28 wks of gestation. Data regarding development of preeclampsia, period of gestation during delivery, mode of delivery, fetal weight and perinatal outcome were recorded and subjected to statistical analysis.

Results: Of the 30 women randomized to receive the drug, ten women were lost to follow-up. Thus only 20 women in the treatment group completed the study. All the 24 women in the control group completed the study. Lycopene was not found to decrease the incidence of pre-eclampsia in high risk women. Women in the lycopene supplementation group had significantly lesser incidence of growth restricted babies and had a significantly better perinatal outcome compared to women in the placebo group.

Conclusion: Lycopene supplementation does not decrease the incidence of preeclampsia in high risk women. However lycopene supplementation does seem to help in reducing the incidence of intrauterine growth restriction.

(J Turkish-German Gynecol Assoc 2011; 12: 35-8)

Key words: Preeclampsia, anti-oxidants, intrauterine growth restriction Received: 26 September, 2010

Accepted: 19 February, 2011

\section{Özet}

Amaç: Yüksek riskli gebe kadınlarda preeklampsinin önlenmesinde antioksidan Likopen'in prenatal takviye edilmesinin etkilerini değerlendirmek. Biz ayrıca preeklampsi geliştirme riski yüksek olan kadınlarda likopen takviyesinin intra-uterin büyüme kısıtlılığı ve perinatal sonuçlar üzerindeki etkisini değerlendirdik.

Gereç ve Yöntemler: Çalışma için preeklampsi geliştirme riski yüksek olan 14-28 gebelik haftası arası toplam 54 kadın irdelendi. Çalışmaya dahil etme kriterleri önceki preeklampsi öyküsü, önceki büyüme geriliği olan fetüs öyküsü, önceki perinatal ölüm öyküsü, çoğul gebelik ve kronik hipertansiyondu. 54 kadından 30 'u, çalışmaya girdikleri tarihte başlamak üzere günde iki kez 2 mg dozunda Likopen alacak şekilde randomize edildi ve doğuma kadar ilaca düzenli şekilde devam etmeleri istendi. Diğer 24 kadın kontrol grubuna randomize edildi ve likopen almadılar. Kontroller preeklampsi gelişimi için risk faktörleri açısından olgularla eşleştirildi. Her iki grup aylık aralarla takip edildi. Ayrıca gebeliğin 28. haftası civarında intrauterin büyüme geriliğinin bir kanıtı olarak Doppler değerlendirmesi yapıldı. Preeklampsi gelişimi, doğumdaki gebelik süresi, doğum şekli, fetüs ağırlığı ve perinatal sonuçlar gibi veriler kaydedildi ve istatistiksel analize tabi tutuldu.

Bulgular: İlacı almak üzere randomize edilen 30 kadından onu takipten düştü. Böylece tedavi grubunda yalnızca 20 kadın çalışmayı tamamladı. Kontrol grubundaki 24 kadının hepsi çalışmayı tamamladı. Likopenin yüksek riskli kadınlarda preeklampsi insidansını düşürmediği bulundu. Plasebo grubundaki kadınlara kıyasla likopen takviyesi grubundaki kadınlarda büyüme kısıtlılığı olan bebek insidansı anlamlı şekilde daha düşüktü ve perinatal sonuçları anlamlı şekilde daha iyiydi. Sonuç: Likopen takviyesi yüksek riskli kadınlarda preeklampsi insidansını düşürmemektedir. Ancak, likopen takviyesi intra-uterin büyüme kısıtlılığı insidansını düşürmeye yardımcı oluyor gibi görünmektedir.

(J Turkish-German Gynecol Assoc 2011; 12: 35-8)

Anahtar kelimeler: Preeklampsi, anti-oksidan, intra-uterin büyüme kısıtlılığı

Geliş Tarihi: 26 Eylül 2010

Kabul Tarihi: 19 Şubat 2011 


\section{Introduction}

Preeclampsia complicates $5 \%$ to $8 \%$ of all (10\% of all pregnancies at our set up) pregnancies. In developing countries, where prenatal care is inadequate, preeclampsia-eclampsia accounts for $40-60 \%$ of maternal deaths, an estimated 50,000 per year. Infants of women with preeclampsia have a 5 -fold increase in mortality compared with infants of mothers without this disorder.

Lycopene is a bright red carotenoid pigment present in tomatoes and other red fruits and vegetables. Structurally, Lycopene is a tetraterpene with eleven conjugated double bonds, which is responsible for the red color and its antioxidant activity. Lycopene is one of the most potent antioxidants found in the human body, having 100 times the antioxidant potency compared to vitamin $\mathrm{E}$ and $\mathrm{C}$. The antioxidant property of Lycopene is believed to be of protective value in many chronic diseases like atherosclerosis and many types of cancer (1).

In this study we studied the effect of lycopene in the prevention of preeclampsia in women who are at high risk of developing preeclampsia. We also study the effect of lycopene supplementation on the perinatal outcome in these groups of women. We searched the Medline and the highwire-press database for similar studies. To our knowledge, no study has been conducted on the effect of lycopene for preventing preeclampsia in high-risk women.

\section{Materials and Methods}

A total of 54 women at high risk of developing pre-eclampsia, who attended antenatal clinic at KIMS, Hubli were considered for the study. A written and informed consent was taken from all women who were to undergo the trial. The ethical review committee of KIMS, Hubli approved the study.

Inclusion criteria: Pregnant women between 14-28 weeks of pregnancy at high risk of developing preeclampsia were included. These are women with a previous history of preeclampsia, a growth-retarded fetus, perinatal death, multifetal gestation and chronic hypertension.

Of the total 54 women, 30 women were randomized to receive Lycopene in a dose of $2 \mathrm{mg}$ twice daily starting from the date of entry and were instructed to continue the drug regularly until delivery. We used the preparation Lycored ${ }^{\circledR}$ (Jagsonpal Pharma, India). The other 24 women were randomized to the control group and they did not take lycopene. We did not use a placebo in the control group due to logistic constraints. The controls were matched to cases with respect to the risk factors for the development of preeclampsia. The alternate women were assigned to cases and controls. Preliminary investigations were conducted in both the groups namely, weight, BP, measurement of urine for protein and obstetric ultrasound. Both cases and controls were supplemented with prenatal iron and calcium supplements.

Both groups were followed at monthly intervals with measurement of the above parameters. In addition, a Doppler assessment for evidence of intrauterine growth retardation was done at around 28 wks of gestation. Data regarding development of preeclampsia, period of gestation during delivery, mode of delivery, fetal weight and perinatal outcome were recorded and subjected to statistical analysis. Intrauterine growth retardation was diagnosed when the abdominal circumference after 28 weeks was less than the $2.5^{\text {th }}$ percentile for the given gestational age and an amniotic fluid index of less than 5.

\section{Results}

Of the 30 women randomized to receive the drug, ten women were lost to follow-up. Thus, only 20 women in the treatment group completed the study. All the 24 women in the control group completed the study. We analyzed data pertaining only to those women who completed the study.

Table 1 shows the characteristics of the women in the two groups. With respect to age, both groups were similar. When parity is considered, the control group had a larger number of women with parity 1 compared to the treatment group. The treatment group had more multiparous patients compared to the control group. Since the recurrent rate of preecalmpsia in subsequent pregnancies is greater with increasing parity, the above distribution of women may not affect the results of the study with respect to development of preeclampsia. As can be inferred from Table 1, both the groups were similar with respect to the risk factors for subsequent development of preeclampsia. More women in the control group had preterm deliveries compared to the women receiving lycopene. However the difference is not statistically significant.

Table 2 shows the principal out the come of trial, which is the development of preeclampsia in both the groups. Thus, although not statistically significant, Lycopene reduces the risk of developing preeclampsia. The odds ratio for developing preeclampsia in

Table 1. The characteristics of women in the two groups

\begin{tabular}{|l|c|c|c|c|}
\hline Characteristics & $\begin{array}{c}\text { Cases } \\
\mathbf{n = 2 0}\end{array}$ & Percent & $\begin{array}{c}\text { Controls } \\
\mathbf{n = 2 4}\end{array}$ & Percent \\
\hline Maternal age in years \\
\hline $18-23$ & 10 & 50 & 16 & 66 \\
\hline $24-28$ & 6 & 30 & 4 & 16.66 \\
\hline$>28$ yrs & 4 & 20 & 4 & 16.66 \\
\hline Parity & 1 & 5 & 0 & 0 \\
\hline Nullipara & 9 & 45 & 17 & 70.83 \\
\hline P1 & 7 & 35 & 5 & 20.83 \\
\hline P2 & 3 & 15 & 2 & 8.33 \\
\hline P3 & 19 & 95 & 22 & 91.66 \\
\hline Risk factors & 1 & 5 & 2 & 8.4 \\
\hline Previous preeclampsia & 19 \\
\hline Multifetal gestation & 1 & 5 & 3 & 12.5 \\
\hline Gestational age at delivery & 8 & 40 & 10 & 41.66 \\
\hline Less than 28 weeks & 1 & 55 & 11 & 45.83 \\
\hline 28-37 weeks & 11 &
\end{tabular}


the control group is 2.3 when compared to the Lycopene using group (Table 2). Thus supplementation with lycopene appears to be 2.3 times more protective than non-supplementation with respect to development of preeclampsia. Table 4 shows the perinatal outcome in the two groups. The perinatal outcome in terms of babies alive at discharge was significantly better in the treatment grocompared to controls.

\section{Discussion}

Preeclampsia can be considered a 2-stage disease, and the linkage of these two stages remains the focus of preeclampsia research $(2,3)$. The first stage of preeclampsia involves abnormal placentation. The failure of the spiral arteries to transform to dilated flaccid tubes with a four-fold increase in diameter, and the frequent finding of atherosis, leads to reduced placental perfusion. The hypoxic placenta releases soluble factors into the maternal circulation, which induces systemic endothelial dysfunction. This causes the second stage of the disease: the maternal syndrome.

The identification of circulating factors mediating endothelial dysfunction has been the source of great research interest for decades. One hypothesis receiving increased attention is that placental and maternal free radical reactions promote a cycle of events that compromise the defensive function of the vascular endothelium in preeclampsia. Recent information indicated that uncontrolled lipid peroxidation may contribute to certain disease processes via disruption of membrane lipids and other cell components.

Markers of lipid peroxidation, including Malondialdehyde and 8-epiprostaglandin F2 $\alpha$ are increased in the plasma of women with preeclampsia, and the low concentration of water-soluble and lipid-soluble antioxidants in the plasma and the placenta $(4,5)$ further suggest a state of oxidative stress. These observations have led to the hypothesis that early supplementation with antioxidants may be effective in decreasing oxidative stress and improving vascular endothelial function, thereby preventing, or ameliorating, the course of preeclampsia.

There is evidence that protective antioxidant systems are deficient in preeclampsia and maternal serum carotenoid levels such as $\beta$-carotene, lycopene and canthaxanthin levels are low in placental tissue and maternal serum (6). Chappel LC et al. (7) studied the effect of antioxidants vitamin $\mathrm{C}$ and vitamin $\mathrm{E}$ on the plasma markers of endothelial activation (plasminogen activator inhibitor PAI-1) and placental dysfunction (PAI-2) and found that antioxidant supplementation decreased the PAI1/ PAI2 ratio by $21 \%$. Sharma JB et al. (8) studied the effect of lycopene on preeclampsia and IUGR in primigravidas and found that lycopene reduces the development of preeclampsia and IUGR in primigravida. In our study Lycopene was started after the $14^{\text {th }}$ week of pregnancy, as the safety of Lycopene in the first trimester is not known.

Pre-eclampsia occurred in 30\% in the treatment group compared to $50 \%$ in the control group. The relative risk of developing preeclampsia is reduced by lycopene $(R R=0.6)$. However, the difference in outcomes between the two groups in terms of developing pre-eclampsia did not reach statistically significant
Table 2. The principal outcome of trial-the development of preeclampsia in both groups

\begin{tabular}{|c|c|c|c|c|}
\hline $\begin{array}{l}\text { Development of } \\
\text { preeclampsia }\end{array}$ & $\begin{array}{l}\text { Cases } \\
n=20\end{array}$ & $\%$ & $\begin{array}{c}\text { Controls } \\
n=24\end{array}$ & $\%$ \\
\hline Preeclampsia occurred & 6 & 30 & 12 & 50 \\
\hline Pre eclampsia not developed & 14 & 70 & 12 & 50 \\
\hline \multicolumn{5}{|c|}{$\begin{array}{l}\text { By applying Fischer's exact test } \\
\mathrm{p}=0.2268 \\
\mathrm{p}>0.05 \text { not significant } \\
\text { Preeclampsia development in Lycopene group compared to control group } \\
\text { Relative risk }=0.6 \\
\text { Preeclampsia development in control compared to lycopene group Odds ratio }=2.3\end{array}$} \\
\hline
\end{tabular}

Table 3. Incidence of IUGR

\begin{tabular}{|l|c|c|c|c|}
\hline Growth parameter & $\begin{array}{c}\text { Cases } \\
\mathbf{n = 2 0}\end{array}$ & $\mathbf{\%}$ & $\begin{array}{c}\text { Controls } \\
\mathbf{n = 2 4}\end{array}$ & $\mathbf{\%}$ \\
\hline IUGR & 1 & 5 & 8 & 33.3 \\
\hline No IUGR & 19 & 95 & 16 & 66.67 \\
\hline $\begin{array}{l}\text { By Fischer's exact test } \\
\text { p=0.0271 } \\
\text { p<0.05 significant. } \\
\text { Relative risk=0.20 }\end{array}$ & & & & \\
\hline
\end{tabular}

Table 4. Perinatal outcome

\begin{tabular}{|l|c|c|c|c|}
\hline Outcome & $\begin{array}{c}\text { Cases } \\
\mathbf{n = 2 0}\end{array}$ & $\mathbf{\%}$ & $\begin{array}{c}\text { Controls } \\
\mathbf{n = 2 4}\end{array}$ & $\mathbf{\%}$ \\
\hline Babies alive at discharge & 19 & 95 & 18 & 75 \\
\hline Perinatal death & 1 & 6 & 6 & 25 \\
\hline $\begin{array}{l}\text { Test of proportions } \\
\mathrm{z}=1.98 \\
\mathrm{p}=0.05 \text { significant }\end{array}$ & \multicolumn{4}{|l}{} \\
\hline
\end{tabular}

levels. The risk of development of preeclampsia following a history of preeclampsia in the first pregnancy was studied by Sibai et al. They reported the recurrence rate of preeclampsia in the second pregnancy to be $46.8 \%$. Sibai et al. (9) in 1991 reported that women with severe preeclampsia which develops in the second trimester are at very high risk of severe preeclampsia in a subsequent pregnancy. In such women, $65 \%$ of all subsequent pregnancies were complicated by preeclampsia. Thus, comparing the pregnancy outcome with lycopene with the above studies, it can be said that lycopene may be modestly effective in preventing recurrence of preeclampsia in the high risk group. However, as the number of subjects in this study is very small we recommend further multicentric studies with large number of subjects for further verification of the results of our trial.

The incidence of IUGR was significantly lower in the study group compared to controls. The incidence of IUGR in the treatment group was 5\% compared to $33 \%$ in the control group $(p<0.05)$. Also, the perinatal outcomes in terms of babies alive at discharge and perinatal death, were better in the lycopene group than controls. There was only one perinatal death in the lycopene-supplemented group, compared to 6 perinatal deaths in the control group. $(\mathrm{p}<0.05)$. Cause of death in the lycopene group was preterm with respiratory distress. All deaths in the 
control group were due to either complications of preterm delivery or to severe IUGR and fetal asphyxia. Thus, we can hypothesize that although lycopene may not prevent the root cause of pre-eclampsia, it might be effective in reducing the complications of pre-eclampsia such as IUGR and perinatal mortality.

The above results could be explained as follows: The exact nature of the initial pathology in pre-eclampsia is not known. Some initial (genetic/fetal/placental factors) event causes the production of free radicals, leading to lipid peroxidation thus setting up a self-perpetuating chain reaction of lipid peroxidation. Antioxidants cannot prevent formation of free radicals and hence cannot alter the basic pathophysiology of pre-eclampsia. However, they might absorb the circulating and tissue free radicals and lipid peroxidation products and limit further damage caused by the lipid peroxidation chain reaction. They might stop the lipid peroxidation chain reaction.

This study shows that antioxidant lycopene, although it may not prevent pre-eclampsia., might help in mitigating fetal complications. This may be due to selective improvements in the fetoplacental circulation compared to the general circulation.

However, large trials with numbers $>1000$ are needed to confirm the findings of the trial.

At present, it might not be possible to prevent preeclampsia at its source, but at least we are able to lessen the burden of its complications on the mother and fetus. With the introduction of magnesium sulfate, an important maternal complication of preeclampsia i.e. eclampsia was prevented. Now hopefully antioxidants will help prevent the fetal complication such as IUGR, fetal asphyxia, and perinatal mortality.
Conflicts of interests: None.

\section{References}

1. Mein JR, Lian F, Wang XD. Biological activity of lycopene metabolites: implications for cancer prevention. Nutr Rev. 2008; 66 : 667-83. [CrossRef]

2. Rinehart BK, Terrone DA, Lagoo-Deenadayalan S, Barber WH, Hale EA, Martin JN Jr, et al. Expression of the placental cytokines TNF $\alpha$, IL-1,IL-1b, IL-10 is increased in preeclampsia. Am. J obstet. Gynecol 1999; 181: 915-20. [CrossRef]

3. Carl A Hubel. Oxidative stress in the pathogenenis of pre-eclampsia. Proc. Soc. Exp. Biol. Med. 1999; 222: 222-35. [CrossRef]

4. Mikhail MS, Anyaegbunam A, Garfinkel D, Palan PR, Basu J, Romney SL. Pre-eclampsia and antioxidant nutrients; decreased plasma levels of Ascorbic acid, $\alpha$ - tocopherol and $\beta$ - carotene in women with eclampsia. Am. J. Obstet Gynecol 1994: 171: 150-7.

5. Wang Y, Walsh SW. Antioxidant activities and mRNA expression of superoxide dismutase, catalase and gluathione peroxidase in normal and preeclamptic placentas. J Soc Gynecol Invest 1996; 3: 179-84. [CrossRef]

6. Palan PR, Mikhail MS, Romeny SL. Placental and serum levels of carotenoids in preeclampsia Obstet Gynecol 2001; 98: 459-62. [CrossRef]

7. Chappell LC, Seed PT, Briley AL, Kelly FJ, Lee R, Hunt BJ, et al. Effect of antioxidants on the occurrence of pre-eclampsia in women at increased risk: a randomised trial. Lancet. 1999; 354: 810-6.

8. Sharma J B, Kumar A, Malhotra M, Arora R, Prasad S, Batra S. Effect of lycopene on preeclampsia and Intrauterine growth retardation in primigravidas Int J Gynaecol obstet 2003 Jun; 81: 257-62.

9. Sibai BM, Mercer B, Sarinoglu C. Severe preeclampsia in the second trimester: recurrence risk and long-term prognosis. Am J Obstet Gynecol. 1991; 165: 1408-12. 